\title{
Two novel species, Lysobacter daejeonensis sp. nov. and Lysobacter yangpyeongensis sp. nov., isolated from Korean greenhouse soils
}

Correspondence

Soon-Wo Kwon swkwon@rda.go.kr

\author{
Hang-Yeon Weon, ${ }^{1}$ Byung-Yong Kim, ${ }^{2}$ Youn-Kyung Baek, ${ }^{2}$ \\ Seung-Hee Yoo, ${ }^{2}$ Soon-Wo Kwon, ${ }^{2}$ Erko Stackebrandt ${ }^{3}$ \\ and Seung-Joo Go ${ }^{2}$
}

\begin{abstract}
${ }^{1}$ Applied Microbiology Division, National Institute of Agricultural Science and Technology, Rural Development Administration (RDA), Suwon 441-707, Republic of Korea

${ }^{2}$ Korean Agricultural Culture Collection (KACC), Genetic Resources Division, National Institute of Agricultural Biotechnology, RDA, Suwon 441-707, Republic of Korea

${ }^{3}$ Deutsche Sammlung von Mikroorganismen und Zellkulturen $\mathrm{GmbH}$, Mascheroder Weg $1 \mathrm{~b}$, D-38124 Braunschweig, Germany
\end{abstract}

Although the genus Lysobacter was first proposed by Christensen \& Cook (1978), the taxonomic properties of its species have not been fully characterized. Recently, Bae et al. (2005) evaluated these properties more deeply and carried out physiological, biochemical, chemotaxonomic and phylogenetic analyses. At the time of writing, the genus Lysobacter includes six species, Lysobacter enzymogenes, Lysobacter antibioticus, Lysobacter brunescens, Lysobacter concretionis, Lysobacter gummosus and Lysobacter koreensis.

Two novel bacterial strains, GH1-9 ${ }^{\mathrm{T}}$ and $\mathrm{GH} 19-3^{\mathrm{T}}$, were isolated from greenhouse soil cultivated with lettuce (Lactuca sativa L.). Soil samples were suspended in sterilized water and diluted solutions were spread on R2A agar (Difco) and incubated at $28^{\circ} \mathrm{C}$. Purified colonies were obtained from

Published online ahead of print on 23 December 2005 as DOI 10.1099/ijs.0.64095-0.

The GenBank/EMBL/DDBJ accession numbers for the 16S rRNA gene sequences of strains $\mathrm{GH} 1-9^{\top}$ and $\mathrm{GH} 19-3^{\top}$ are DQ191178 and DQ191179, respectively. subcultures. Cellular morphology was determined by using phase-contrast microscopy with 2-day-old cells. Motility was examined by using $1 / 10$ strength R2A medium, and gliding motility was observed by oil-immersion phase-contrast microscopy of the edges of colonies of cells in exponential phase. The temperature range $\left(4-50^{\circ} \mathrm{C}\right), \mathrm{pH}$ range $(4-10$ at intervals of $1 \mathrm{pH}$ unit) and the requirement for $0,1,2,3,5$ and $7 \% \mathrm{NaCl}(\mathrm{w} / \mathrm{v})$ for growth were determined using $\mathrm{R} 2 \mathrm{~A}$ medium. Gram staining, and tests for catalase and oxidase, indole production and hydrolysis of casein, chitin, DNA, gelatin and starch were conducted according to the methods of Smibert \& Krieg (1994). Carboxymethylcellulose (CMcellulose; $0 \cdot 1 \%$, w/v; Sigma) and Whatman powder CF11 $(0 \cdot 1 \%, \mathrm{w} / \mathrm{v})$ were used to test for cellulase. Hydrolysis of chitin from crab shells $(1 \%, \mathrm{w} / \mathrm{v}$; Sigma) and tyrosine $(0.5 \%, \mathrm{w} / \mathrm{v})$ was also tested. API $20 \mathrm{NE}$, API ID $32 \mathrm{GN}$ and API ZYM kits (bioMérieux) were used to determine biochemical properties, utilization of carbohydrates and enzymic activities, according to the manufacturer's instructions. The API ZYM tests were read after $4 \mathrm{~h}$ incubation at $37^{\circ} \mathrm{C}$ and the other API tests after $72 \mathrm{~h}$ at $28^{\circ} \mathrm{C}$. 
The two strains were aerobic, with rod-shaped cells $(0 \cdot 4-$ $0.6 \times 3 \cdot 0-4 \cdot 0 \mu \mathrm{m})$. Colonies of both strains were yellow, circular and convex, with clear margins after 2 days incubation on R2A agar. Both strains grew well on R2A and nutrient agar (Difco), but did not grow on MacConkey agar (Difco). Growth on trypticase soy agar (Difco) was observed on initial inoculation, but no growth was observed after the strains had been subcultured three or four times. With a longer incubation time ( $>1$ week), the centre of the colonies of strain GH19-3 $3^{\mathrm{T}}$ developed a brown colour. Using the API $20 \mathrm{NE}$ and API ID 32 GN kits, strain GH1- $9^{\mathrm{T}}$ tested positive for nitrate reduction and aesculin hydrolysis, and assimilated D-maltose, sodium acetate, glycogen, D-glucose, valeric acid and 3-hydroxybutyric acid. Strain GH19- $3^{\mathrm{T}}$ tested positive for gelatin hydrolysis and assimilated glycogen and 3-hydroxybutyric acid. Using API ZYM, strain GH1- $9^{\mathrm{T}}$ was positive for alkaline phosphatase, esterase C4, esterase lipase C8, leucine arylamidase, trypsin, acid phosphatase, naphthol-AS-BI-phosphohydrolase and $\alpha$-glucosidase, and weakly positive for lipase C14, valine arylamidase and $\beta$-glucosidase. Strain $\mathrm{GH} 19-3^{\mathrm{T}}$ was positive for alkaline phosphatase, esterase $\mathrm{C} 4$, esterase lipase $\mathrm{C} 8$, leucine arylamidase, valine arylamidase, acid phosphatase, naphthol-AS-BI-phosphohydrolase and $\alpha$ glucosidase, and weakly positive for $\alpha$-chymotrypsin and $N$-acetyl- $\beta$-glucosaminidase. Phenotypic characteristics of the two strains are given in the species descriptions. Phenotypic characteristics that differentiated the two strains and other related Lysobacter species are shown in Table 1.

Isoprenoid quinones were analysed by HPLC as described by Groth et al. (1996). Analysis of the respiratory lipoquinones indicated that the two isolates contained ubiquinone8 (Q-8). This quinone system is a characteristic feature of members of the genus Lysobacter (Bae et al., 2005). The DNA G $+C$ content was determined as described by Mesbah et al. (1989) using a reversed-phase column (Supelcosil LC18-S; Supelco). The G+C contents of strains GH1- $9^{\mathrm{T}}$ and GH19-3 $3^{\mathrm{T}}$ were $61 \cdot 7$ and $67 \cdot 3 \mathrm{~mol} \%$, respectively.

Table 1. Phenotypic characteristics of strains $\mathrm{GH} 1-9^{\top}, \mathrm{GH} 19-3^{\top}$ and other Lysobacter species

Taxa: 1, GH1-9 ${ }^{\mathrm{T}}$; 2, GH19-3 ${ }^{\mathrm{T}}$; 3, L. enzymogenes DSM 2043 $;$ 4, L. antibioticus DSM 2044 ${ }^{\mathrm{T}}$; 5, L. brunescens ATCC $29482^{\mathrm{T}}$; 6, L. concretionis DSM 16239 ; 7, L. gummosus ATCC 29489 ; 8, L. koreensis KCTC 12204 ${ }^{\mathrm{T}}$. Data from Christensen (1989), Bae et al. (2005), Lee et al. (2006) and this study. +, Positive; -, negative; W, weak; ND, not determined.

\begin{tabular}{|c|c|c|c|c|c|c|c|c|}
\hline Characteristic & 1 & 2 & 3 & 4 & 5 & 6 & 7 & 8 \\
\hline \multirow[t]{2}{*}{ Cell size $(\mu \mathrm{m})$} & $0 \cdot 4-0 \cdot 6$ & $0 \cdot 4-0 \cdot 6$ & $0 \cdot 5 \times 38 \cdot 0$ & $0 \cdot 4-6 \cdot 5$ & $0 \cdot 3-11 \cdot 0$ & $0 \cdot 7 \times 1 \cdot 0$ & $0 \cdot 4 \times 2 \cdot 0$ & $0 \cdot 5-0 \cdot 8$ \\
\hline & $\times 3 \cdot 0-4 \cdot 0$ & $\times 3 \cdot 0-4 \cdot 0$ & & & & $-13 \cdot 5$ & & $\times 1 \cdot 5-2 \cdot 0$ \\
\hline Gliding motility & - & - & + & + & + & + & + & ND \\
\hline Catalase/oxidase & $\mathrm{w} /+$ & $-1+$ & $+1+$ & $+1+$ & $+1+$ & $+1+$ & $+/ \mathrm{ND}$ & $+1-$ \\
\hline Aesculin hydrolysis & + & - & + & + & + & - & + & - \\
\hline Indole production & - & - & - & - & + & - & - & - \\
\hline Glucose acidification & - & - & + & + & - & - & - & - \\
\hline Arginine dihydrolase & - & - & - & - & + & - & - & - \\
\hline Urease & - & - & - & - & + & - & - & - \\
\hline$\beta$-Galactosidase & - & - & + & + & - & - & + & - \\
\hline \multicolumn{9}{|l|}{ Growth on: } \\
\hline$N$-Acetylglucosamine & - & - & + & - & - & - & + & - \\
\hline D-Maltose & + & - & + & + & - & - & + & - \\
\hline Acetate & + & - & - & - & + & + & + & - \\
\hline Glycogen & + & + & + & + & - & + & + & - \\
\hline L-Serine & - & - & + & - & - & - & - & + \\
\hline D-Glucose & + & - & + & - & - & - & + & - \\
\hline Salicin & - & - & + & - & - & - & - & - \\
\hline D-Melibiose & - & - & + & - & - & - & + & - \\
\hline Arabinose & - & - & - & - & - & - & + & + \\
\hline Valerate & + & - & - & + & - & + & + & + \\
\hline Citrate & - & - & + & - & - & - & + & + \\
\hline Histidine & - & - & - & - & - & - & + & - \\
\hline 3-Hydroxybutyrate & + & + & + & + & - & + & + & - \\
\hline L-Proline & - & - & + & + & - & + & + & - \\
\hline Mannose & - & - & + & + & - & - & - & - \\
\hline Malate & - & - & + & - & - & - & - & - \\
\hline $\mathrm{G}+\mathrm{C}$ content $(\mathrm{mol} \%)$ & $61 \cdot 7$ & $67 \cdot 3$ & $69 \cdot 0$ & $69 \cdot 2$ & $67 \cdot 7$ & $63 \cdot 8$ & $65 \cdot 7$ & $68 \cdot 9$ \\
\hline
\end{tabular}


After growth of the cells on R2A agar for $48 \mathrm{~h}$ at $28^{\circ} \mathrm{C}$, fatty acid methyl esters were extracted and prepared by using the standard protocol of the Microbial Identification System (MIDI; Microbial ID). The major fatty acids of strain GH1$9^{\mathrm{T}}$ were iso- $\mathrm{C}_{16: 0}$, iso- $\mathrm{C}_{15: 0}$, iso- $\mathrm{C}_{14: 0}$, iso- $\mathrm{C}_{17: 1} \omega 9 c$ and iso- $\mathrm{C}_{11: 0} 3-\mathrm{OH}$ and the major fatty acids of strain $\mathrm{GH} 19-3^{\mathrm{T}}$ were iso- $\mathrm{C}_{16: 0}$, iso- $\mathrm{C}_{15: 0}, \mathrm{C}_{16: 1} \omega 7 c$ alcohol, iso- $\mathrm{C}_{17: 1} \omega 9 c$ and iso- $\mathrm{C}_{11: 0} 3-\mathrm{OH}$. The characteristic fatty acid of the two isolates that differentiated them from the other Lysobacter species was iso- $\mathrm{C}_{12: 0} 3-\mathrm{OH}$. A unique fatty acid component of GH1 $-9^{\mathrm{T}}$ was iso- $\mathrm{C}_{15: 1} \mathrm{~F}$. Unique fatty acid components of strain $\mathrm{GH} 19-3^{\mathrm{T}}$ were anteiso- $\mathrm{C}_{17: 0}$ and $\mathrm{C}_{10: 0} 3-\mathrm{OH}$. A comparison of fatty acid profiles among Lysobacter species is shown in Table 2.

The 16S rRNA gene was amplified by PCR (Kwon et al., 2003). The products were sequenced directly using an ABI PRISM BigDye Primer cycle sequencing kit (Applied Biosystems) with an ABI 3700 DNA sequencer (Applied Biosystems). The 16S rRNA gene sequences of the two isolates were aligned with reference sequences of Lysobacter species and members of related genera. Escherichia coli (GenBank accession no. J01695) was used as an outgroup. Sequences were aligned using the multiple sequence alignment program CLUSTAL W (Thompson et al., 1994). Phylogenetic distances were determined according to Jukes \& Cantor (1969) and a tree was constructed by using the neighbour-joining method (Saitou \& Nei, 1987) as implemented in MEGA version 2.1.

According to the phylogenetic tree (Fig. 1), the two isolates were clearly grouped in a cluster composed of Lysobacter species except for L. brunescens ATCC $29482^{\mathrm{T}}$. The sequence similarity between strains $\mathrm{GH} 1-9^{\mathrm{T}}$ and $\mathrm{GH} 19-3^{\mathrm{T}}$ was $95 \cdot 3 \%$. The neighbour-joining tree indicated that strain GH1 $-9^{\mathrm{T}}$ was most highly related to $L$. concretionis DSM $16239^{\mathrm{T}}\left(96 \cdot 4 \%\right.$ sequence similarity) and strain GH19-3 $3^{\mathrm{T}}$ showed the highest sequence similarity with $L$. enzymogenes DSM $2043^{\mathrm{T}}(96 \cdot 6 \%)$. The low level of $16 \mathrm{~S}$ rRNA gene sequence similarity ( $<97 \%$ ) among Lysobacter species with

Table 2. Cellular fatty acid content of strains $\mathrm{GH} 1-9^{\top}$ and $\mathrm{GH} 19-3^{\top}$ compared with other related species

Taxa: 1, GH1-9 ${ }^{\mathrm{T}} ; 2$, GH19-3 ${ }^{\mathrm{T}} ; 3$, L. enzymogenes DSM 2043 ${ }^{\mathrm{T}} ; 4$, L. antibioticus DSM $2044^{\mathrm{T}}$; 5, L. brunescens ATCC $29482^{\mathrm{T}}$; 6, L. concretionis DSM 16239 ${ }^{\mathrm{T}}$; 7, L. gummosus ATCC $29489^{\mathrm{T}}$; 8, L. koreensis KCTC $12204^{\mathrm{T}}$. Data from Bae et al. (2005), Lee et al. (2006) and this study. Results are presented as a percentage of the total fatty acids. - , Not detected.

\begin{tabular}{|c|c|c|c|c|c|c|c|c|}
\hline Fatty acid & 1 & 2 & 3 & 4 & 5 & 6 & 7 & 8 \\
\hline iso- $\mathrm{C}_{10: 0}$ & $0 \cdot 9$ & $0 \cdot 9$ & - & - & - & - & - & $0 \cdot 7$ \\
\hline iso- $\mathrm{C}_{11: 0}$ & $3 \cdot 7$ & $4 \cdot 3$ & $4 \cdot 3$ & $3 \cdot 5$ & $7 \cdot 0$ & $6 \cdot 4$ & $4 \cdot 0$ & $3 \cdot 5$ \\
\hline iso- $\mathrm{C}_{11: 0} 3-\mathrm{OH}$ & $6 \cdot 0$ & $5 \cdot 5$ & $6 \cdot 0$ & $5 \cdot 2$ & $5 \cdot 6$ & $5 \cdot 6$ & $4 \cdot 4$ & $5 \cdot 6$ \\
\hline iso- $\mathrm{C}_{12: 0}$ & $2 \cdot 0$ & $1 \cdot 2$ & - & - & - & - & - & $0 \cdot 7$ \\
\hline $\mathrm{C}_{14: 0}$ & $0 \cdot 9$ & - & $1 \cdot 2$ & $1 \cdot 7$ & $0 \cdot 7$ & $0 \cdot 8$ & - & - \\
\hline iso- $\mathrm{C}_{14: 0}$ & $11 \cdot 2$ & $4 \cdot 5$ & - & $2 \cdot 3$ & $6 \cdot 7$ & $2 \cdot 6$ & - & $2 \cdot 7$ \\
\hline iso- $\mathrm{C}_{15: 0}$ & $13 \cdot 1$ & $14 \cdot 5$ & $43 \cdot 0$ & $19 \cdot 9$ & $23 \cdot 8$ & $36 \cdot 1$ & $39 \cdot 3$ & $17 \cdot 0$ \\
\hline iso- $\mathrm{C}_{15: 1}$ AT5 & - & $3 \cdot 1$ & - & - & - & - & - & $2 \cdot 7$ \\
\hline anteiso- $\mathrm{C}_{15: 0}$ & $3 \cdot 2$ & $5 \cdot 1$ & $1 \cdot 9$ & $5 \cdot 4$ & $1 \cdot 7$ & $1 \cdot 2$ & $5 \cdot 1$ & - \\
\hline $\mathrm{C}_{16: 1} \omega 7 c$ alcohol & - & $8 \cdot 8$ & - & $3 \cdot 0$ & $0 \cdot 8$ & - & $1 \cdot 1$ & $4 \cdot 1$ \\
\hline $\mathrm{C}_{16: 1} \omega 11 c$ & - & $2 \cdot 2$ & - & $5 \cdot 5$ & - & - & - & - \\
\hline iso- $\mathrm{C}_{17: 0}$ & $0 \cdot 5$ & $1 \cdot 9$ & $4 \cdot 4$ & $1 \cdot 9$ & $0 \cdot 7$ & $2 \cdot 9$ & $13 \cdot 0$ & $2 \cdot 5$ \\
\hline iso- $\mathrm{C}_{17: 1} \omega 9 c$ & $6 \cdot 7$ & $6 \cdot 7$ & $8 \cdot 8$ & $4 \cdot 5$ & $11 \cdot 5$ & $13 \cdot 9$ & $12 \cdot 6$ & $19 \cdot 9$ \\
\hline anteiso- $\mathrm{C}_{17: 0}$ & - & $1 \cdot 1$ & - & - & - & - & - & - \\
\hline $\mathrm{C}_{17: 0}$ cyclo & - & - & $10 \cdot 6$ & $8 \cdot 1$ & - & $2 \cdot 5$ & - & - \\
\hline $\mathrm{C}_{18: 0}$ & - & - & - & - & - & - & - & $1 \cdot 0$ \\
\hline iso- $\mathrm{C}_{18: 0}$ & - & $0 \cdot 8$ & - & - & - & - & - & $0 \cdot 9$ \\
\hline Summed feature $4^{*}$ & $6 \cdot 1$ & $3 \cdot 3$ & $8 \cdot 3$ & $11 \cdot 2$ & $9 \cdot 0$ & $0 \cdot 9$ & $4 \cdot 9$ & $2 \cdot 1$ \\
\hline Summed feature $7^{\star}$ & - & - & $1 \cdot 6$ & $1 \cdot 3$ & - & - & - & - \\
\hline
\end{tabular}

${ }^{*}$ Summed feature 4 comprises iso- $\mathrm{C}_{15: 0} 2-\mathrm{OH}$ and/or $\mathrm{C}_{16: 1} \omega 7 c$; summed feature 7 comprises $\mathrm{C}_{18: 1} \omega 7 c / \omega 9 t / \omega 12 t$ and/or $\mathrm{C}_{18: 1} \omega 7 c / \omega 9 c / \omega 12 t$, which could not be separated by the MIDI system. 


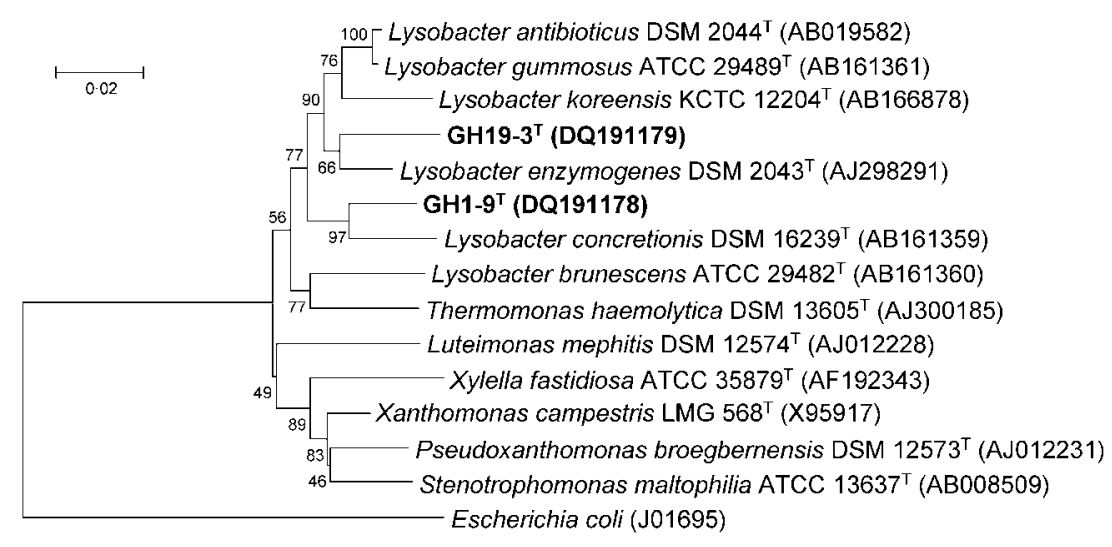

Fig. 1. Phylogenetic relatedness of strains $\mathrm{GH} 1-9^{\top}$ and $\mathrm{GH} 19-3^{\top}$ and the type strains of recognized Lysobacter species based on 16S rRNA gene sequence comparison. Some related genera were also used and $E$. coli served as a root. The dendrogram was generated by using neighbour-joining analysis (Saitou \& Nei, 1987). Numbers indicate percentages of occurrence of the branching order in 1000 bootstrapped trees. Bar, 2 substitutions per $100 \mathrm{nt}$. validly published names and the novel isolates indicated that the two isolates each represented novel genomic species of the genus Lysobacter. Consequently, DNA-DNA reassociation studies were not necessary (Stackebrandt \& Goebel, 1994). Therefore, based on the polyphasic taxonomic approach described here, we propose the name Lysobacter daejeonensis sp. nov. for isolate $\mathrm{GH} 1-9^{\mathrm{T}}$ and Lysobacter yangpyeongensis sp. nov. for isolate $\mathrm{GH} 19-3^{\mathrm{T}}$.

\section{Description of Lysobacter daejeonensis sp. nov.}

Lysobacter daejeonensis (dae.je.on.en'sis. N.L. masc. adj. daejeonensis pertaining to Daejeon, a city in Korea, from where the type strain was isolated).

Cells are aerobic, Gram-negative, non-motile and rodshaped $(0 \cdot 4-0 \cdot 6 \times 3 \cdot 0-4 \cdot 0 \mu \mathrm{m}$ in size). Colonies are yellow, circular and convex, with clear margins after 2 days incubation on $\mathrm{R} 2 \mathrm{~A}$ agar. $\mathrm{NaCl}$, temperature and $\mathrm{pH}$ ranges for growth are $0-3 \%(\mathrm{w} / \mathrm{v}), 10-37^{\circ} \mathrm{C}$ and $6-8$, respectively. Does not hydrolyse chitin, CM-cellulose, Whatman powder CF11 or starch, but does hydrolyse casein, DNA, gelatin and tyrosine. Major fatty acids are iso- $\mathrm{C}_{16: 0}(33 \cdot 7 \%)$, iso$\mathrm{C}_{15: 0}(13 \cdot 1 \%)$, iso- $\mathrm{C}_{14: 0}(11 \cdot 2 \%)$, iso- $\mathrm{C}_{17: 1} \omega 9 c(6 \cdot 7 \%)$ and iso- $\mathrm{C}_{11: 0} 3-\mathrm{OH}(6 \cdot 0 \%)$. Contains Q- 8 . The $\mathrm{G}+\mathrm{C}$ content of the genomic DNA is $61.7 \mathrm{~mol} \%$ (HPLC). Additional characteristics are listed in Table 1.

The type strain, GH1-9 $9^{\mathrm{T}}\left(=\right.$ KACC $\left.11406^{\mathrm{T}}=\mathrm{DSM} 17634^{\mathrm{T}}\right)$, was isolated from greenhouse soil in Korea.

\section{Description of Lysobacter yangpyeongensis sp. nov.}

Lysobacter yangpyeongensis (yang.pye.ong.en'sis. N.L. masc. adj. yangpyeongensis pertaining to Yangpyeong, a province in Korea, from where the type strain was isolated).

Cells are aerobic, Gram-negative, motile and rod-shaped $(0 \cdot 4-0 \cdot 6 \times 3 \cdot 0-4 \cdot 0 \mu \mathrm{m}$ in size $)$. Colonies are yellow, circular and convex, with clear margins after 2 days incubation on R2A agar. Temperature and $\mathrm{pH}$ ranges for growth are $15-40{ }^{\circ} \mathrm{C}$ and $5-8$, respectively. Does not grow in $1 \%(\mathrm{w} / \mathrm{v})$ $\mathrm{NaCl}$. Hydrolyses casein, DNA, gelatin, starch and tyrosine, but not chitin, CM-cellulose or Whatman powder CF11. Major fatty acids are iso- $\mathrm{C}_{16: 0}(27 \cdot 5 \%)$, iso- $\mathrm{C}_{15: 0}(14 \cdot 5 \%)$, $\mathrm{C}_{16: 1} \omega 7 c$ alcohol $(8 \cdot 8 \%)$, iso- $\mathrm{C}_{17: 1} \omega 9 c(6.7 \%)$ and iso$\mathrm{C}_{11: 0} 3-\mathrm{OH}(5 \cdot 5 \%)$. Contains Q- 8 . The $\mathrm{G}+\mathrm{C}$ content of the genomic DNA is $67 \cdot 3 \mathrm{~mol} \%$ (HPLC). Additional characteristics are listed in Table 1.

The type strain, GH19-3 ${ }^{\mathrm{T}}\left(=\right.$ KACC $\left.11407^{\mathrm{T}}=\mathrm{DSM} 17635^{\mathrm{T}}\right)$, was isolated from greenhouse soil in Korea.

\section{References}

Bae, H.-S., Im, W.-T. \& Lee, S.-T. (2005). Lysobacter concretionis sp. nov., isolated from anaerobic granules in an upflow anaerobic sludge blanket reactor. Int J Syst Evol Microbiol 55, 1155-1161.

Christensen, P. (1989). Genus I. Lysobacter Christensen and Cook $1978,372^{\mathrm{AL}}$. In Bergey's Manual of Systematic Bacteriology, vol. 3, pp. 2083-2089. Edited by J. T. Staley, M. P. Bryant, N. Pfennig \& J. G. Holt. Baltimore: Williams \& Wilkins.

Christensen, P. \& Cook, F. D. (1978). Lysobacter, a new genus of nonfruiting, gliding bacteria with a high base ratio. Int $J$ Syst Bacteriol 28, 367-393.

Groth, I., Schumann, P., Weiss, N., Martin, K. \& Rainey, F. A. (1996). Agrococcus jenensis gen. nov., sp. nov., a new genus of actinomycetes with diaminobutyric acid in the cell wall. Int J Syst Bacteriol 46, 234-239.

Jukes, T. H. \& Cantor, C. R. (1969). Evolution of protein molecules. In Mammalian Protein Metabolism, pp. 21-132. Edited by H. N. Munro. New York: Academic Press.

Kwon, S. W., Kim, J. S., Park, I. C., Yoon, S. H., Park, D. H., Lim, C. K. \& Go, S. J. (2003). Pseudomonas koreensis sp. nov., Pseudomonas umsongensis sp. nov. and Pseudomonas jinjuensis sp. nov., novel species from farm soils in Korea. Int J Syst Evol Microbiol 53, 21-27.

Lee, J. W., Im, W.-T., Kim, M. K. \& Yang, D.-C. (2006). Lysobacter koreensis sp. nov., isolated from a ginseng field. Int $J$ Syst Evol Microbiol 56, 231-235.

Mesbah, M., Premachandran, U. \& Whitman, W. B. (1989). Precise measurement of the $\mathrm{G}+\mathrm{C}$ content of deoxyribonucleic acid by highperformance liquid chromatography. Int J Syst Bacteriol 39, 159-167.

Saitou, N. \& Nei, M. (1987). The neighbor-joining method: a new method for reconstructing phylogenetic trees. Mol Biol Evol 4, 406-425.

Smibert, R. M. \& Krieg, N. R. (1994). Phenotypic characterization. In Methods for General and Molecular Bacteriology, pp. 607-654. Edited by P. Gerhardt, R. G. E. Murray, W. A. Wood \& N. R. Krieg. Washington, DC: American Society for Microbiology. 
Stackebrandt, E. \& Goebel, B. M. (1994). Taxonomic note: a place for DNA-DNA reassociation and 16S rRNA sequence analysis in the present species definition in bacteriology. Int J Syst Bacteriol 44, 846-849.
Thompson, J. D., Higgins, D. G. \& Gibson, T. J. (1994). CLUSTAL W: improving the sensitivity of progressive multiple sequence alignment through sequence weighting, position-specific gap penalties and weight matrix choice. Nucleic Acids Res 22, 4673-4680. 